\title{
POTENSI DAN PERAN PESANTREN DALAM MENGEMBANGKAN EKONOMI MASYARAKAT
}

\author{
Moh. Wadi \\ STAI Miftahul Ulum Pamekasan \\ wadiallsalam@gmail.com
}

\begin{abstract}
Islamic boarding schools have an important role for the independence of Indonesia and also play a role in developing the community's economy in order to assist the government in efforts to reduce poverty and unemployment. Tne example is the economic activity carried out by the Miftahul Ulum Islamic Boarding School in Panyeppen Palengaan Pamekasan. The results of the study indicate that the potential of pesantren in developing the community's economy are formal education, students, alumni, sympathizers, community and branch/affiliated madrasas. The roles and activities of Islamic boarding schools in developing the community's economy are first, by providing business capital through qard al-hasan and business capital lending for people who lack and need business capital accompanied by intensive and periodic entrepreneurship training. Second, by providing job opportunities by becoming employees at economic institutions and educational institutions managed by the Al-Miftah foundation such as employees of BMT, KOIM Swalayan. Third, by providing kios for the public to be able to trade. Fourth, the provision of scholarships to outstanding students is to develop children's education. Supporting factors, namely the ideals of caregivers, empowering human resources, cooperation with other institutions and consumers are permanent and clear, while the inhibiting factors are increasingly fierce and competitive competition, limited employee knowledge, time-consuming efforts and the sudden arrival of natural risks.
\end{abstract}

Keywords: The potential of pesantren, the role of pesantren and the community economy.

\begin{abstract}
Abstrak: Pesantren mempunyai peranan penting dalam kemerdekaan Indonesia dan juga peran dalam mengembangkan ekonomi masyarakat guna untuk membantu pemerintah dalam usaha mengurangi kemiskinan dan pengangguran, salah satu contoh adalah aktivitas ekonomi yang dilakukan oleh Pondok Pesantren Miftahul Ulum Panyeppen Palengaan Pamekasan. Hasil penelitian menunjukkan bahwa Potensi yang dimiliki pesantren dalam mengembangkan ekonomi masyarakat adalah pendidikan formal, santri, alumni, simpatisan, masyarakat dan madrasah ranting/berafiliasi. Peran dan aktifitas pesantren dalam mengembangkan ekonomi masyarakat pertama pemberian modal usaha melalui qard al-hasan dan peminjaman modal usaha untuk masyarakat yang kekurangan dan membutuhkan modal usaha yang disertai dengan pelatihan kewirausahaan secara intensif dan berkala, kedua penyediaan lapangan pekerjaan dengan menjadi karyawan pada lembaga ekonomi dan intansi pendidikan yang dikelola oleh yayasan Al-Miftah seperti karyawan BMT, KOIM Swalayan. ketiga penyedian kios-kios untuk masyarakat bisa berdagang. keempat pemberian biasiswa pada santri berprestasi hal ini untuk mengembangkan pendidikan anak. Faktor pendukung yaitu cita-cita pengasuh, pemberdayaan SDM, kerjasama dengan lembaga lain dan konsumen tetap dan jelas, adapun faktor
\end{abstract}

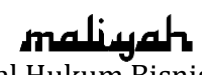

Jurnal Hukum Bisnis Islam

Volume 10, Nomor 01, Juni 2020

p-ISSN: 2088-4869/ e-ISSN: 2597-4351 
penghambat adalah persaingan semakin ketat dan kompetitif, keterbatasan knowledge karyawan, usaha berjangka waktu dan datangnya risiko alam secara tibatiba.

Kata Kunci: Potensi pesantren, peran pesantren dan ekonomi masyarakat.

\section{Pendahuluan}

Pondok pesantren adalah lembaga pendidikan keagamaan yang memerankan fungsi sebagai institusi sosial. ${ }^{1}$ Sebagai institusi sosial pesantren memiliki dan menjadi pedoman etika bagi masyarakat, karena pesantren adalah institusi yang melegitimasi berbagai moralitas yang seharusnya ada dalam masyarakat, karena institusi sosial pada hakikatnya muncul dan berkembang berkat tuntutan dan kebutuhan masyarakat. Pesantren merupakan produk sejarah yang terus berkembang mengikuti zaman, masing-masing memiliki karakteristik berlainan baik menyangkut sosio-politik, sosiokultural, sosio-ekonomi maupun sosio-religius. Antara pesantren dan masyarakat sekitar, khususnya masyarakat desa, telah terjalin interaksi yang harmonis, bahkan keterlibatan mereka cukup besar dalam mendirikan pesantren. Sebaliknya kontribusi yang relatif besar acapkali dihadiahkan pesantren untuk pembangunan masyarakat desa, ${ }^{2}$ maka peran pesantren sangat diperlukan untuk mengembangkan masyarakat termasuk dalam sektor ekomoni yang menghimpit masyarakat.

Salah satu pondok pesantren sebagai lembaga dakwah yang andil dalam pengembangan masyarakat dan kemajuan ekonomi guna untuk menjaga keberlangsungan kesejahteraan pondok pesantren dan membantu mengembangkan ekonomi masyarakat adalah Pondok Pesantren Miftahul Ulum Panyeppen Pamekasan yang berdiri sejak tahun $1827 \mathrm{M}$,

1 Nur Syam, Kepemimpinan Dalam Pengembangan Pondok Pesantren, Manajemen Pesantren (Yogyakarta: Pustaka Pesantren, 2005). 78

2 Yusni Fauzi, "Peran Pesantren Dalam Upaya Pengembangan Manajemen Sumber Daya Manusia (MSDM) Entrepreneurship, (Penelitian Kualitatif Di Pondok Pesantren Al-Ittifaq Rancabali Bandung)," Jurnal Pendidikan Universitas Garut Vol.06 No. (n.d.): 4. 
Pondok Pesantren ini didirikan oleh KH. Nashrudin bin Itsbat di Kampung Panyepen, Desa Poto'an Laok, Palengaan, Pamekasan Maduara (11 km dari kota Pamekasan ke arah Barat Laut), yang diasuh oleh KH. Muddatstsir Badruddin mulai tahun 1971- sekarang. ${ }^{3}$ Pondok Pesantren Miftahul Ulum Panyeppen selalu mengedepankan ajaran ulama salaf dengan berbagai kegiatan keagamaan seperti kajian kitab kuning, musyawaroh tentang fiqih, itu juga dibuktikan dengan berdirinya madrasah diniyah dari tingkat ula, wustha dan ulya guna untuk mencetak santrinya sebagai generasi yang selalu menjaga tradisi salaf dari berbagai aspek kehidupannya sebagaimana yang telah diajarkan oleh Allah SWT kepada Nabi Muhamad SAW melalui Malaikat Jibril.

Berdirinya beberapa lembaga dengan bermacammacam jurusan dan fungsi, Pondok Pesantren Miftahul Ulum Panyeppen memiliki potensi besar untuk menjadi lembaga yang bisa mengorbitkan output yang siap untuk membantu dalam semua aktivitas yang disiapkan oleh masyarakat utamanya aktivitas yang berkaitan dengan pesantren, hal ini pondok pesantren mengharapkan santri untuk bisa bersaing bukan hanya urusan ilmu agama tetapi juga bisa bersaing dengan berkembangnya teknologi, santri diharapkan siap bekerja dan membantu masyarakat dalam berbagai sektor.

Sejak berdirinya Pondok Pesantren Miftahul Ulum Panyeppen Pamekasan sampai sekarang, tentu pondok pesantren ini memiliki peran yang tidak kecil dalam pengembangan masyarakat baik sebagai sub sistem pendidikan, pembangunan sosio kultural maupun dalam pengembangan ekonomi masyarakat, karena pengelolaan pondok pesantren dibidang pendidikan dan spritual sering kali dianggap meninggalkan pengembangan usaha ekonomi sebagai salah satu penunjang keberlangsungan pondok pesantren dari berbagai sektor, sehingga perlu ditanamkan wacana dan

3 Tim An-najah, Jejak Langkah Dan Kiprah Para Masyayikh Panyeppen (Pamekasan: Al Miftah Press, 2013).107 
konsep kemandirian ekonomi melalui pelaksanaan usaha produktif atau bisnis yang memberi imbal hasil kepada pondok pesantren dan masyarakat sebagaimana yang dilakukan oleh Pondok Pesantren Miftahul Ulum Panyeppen.

Fenomena yang menarik diteliti adalah keterlibatan Pondok Pesantren Miftahul Ulum Panyeppen sebagai salah satu lembaga pendidikan agama Islam yang juga mempunyai fungsi pemberdayaan masyarakat (agen of development) dan lembaga yang mempunyai misi untuk menjadi lembaga yang membawa perubahan sosial (social change), itu terlihat dari beberapa kegiatan dan lembaga-lembaga yang berada di lingkungan pondok pesantren, yang pertama adalah potensi yang dimiliki mulai dari santri, alumni, simpatisan dan masyarakat dengan dikuatkan kemajuan pendidikan yang sampai pada tingkat perguruan tinggi serta pelatihan-pelatihan dan diklat yang bisa menambah wawasannya pada berbagai pengetahuan seperti pelatihan leadership dan kewirausahaan. Kedua penyediaan lembaga pengembangan ekonomi yang berbasis ekonomi ummat seperti lembaga keuangan shariah (BMT Mawaddah) yang dapat membantu masyarakat untuk peminjaman modal usaha serta pertokoan dan ritel (KOIM Swalayan) yang berada di lingkungan pesantren dan di beberapa wilayah. Ketiga adalah pelatihan kewirausahaan terhadap masyarakat secara berkala guna untuk membantu dan memberi peluang pada masyarakat untuk mengembangkan dan meningkatkan ekonominya dan keempat peran aktif masyarakat dalam setiap kegiatan pesantren utamanya dalam kegiatan pengembangan ekonomi.

Sekalipun Pondok Pesantren Miftahul Ulum Panyeppen termasuk lembaga sosial yang mengembangkan ekonomi masyarakat, namun pada hakikatnya tetap sebagai lembaga pendidikan Islam dan dakwah yang mempunyai ciri-ciri dalam gerakannya. Dengan ini, lembaga pondok pesantren memasuki tahapan modernisasi dengan pola mengembangkan kemaslahatan ummat/masyarakat sebagai sasarannya. Dengan demikian bisa saja pondok pesantren memiliki dimensi fungsi setelah melakukan pembaharuan terhadap lingkungan yang 
berkembang. Berangkat dari latar belakang di atas, maka peneliti perlu melakukan penelitian dengan judul tesis "Potensi dan Peran Pesantren dalam Mengembangkan Ekonomi Masyarakat Studi pada Pondok Pesantren Miftahul Ulum Panyeppen Pamekasan"

\section{Konsep Pondok Pesantren}

Pesantren adalah lembaga pendidikan Islam tradisional di Indonesia yang sudah tumbuh dan berkembang beberapa abad yang lalu. Kata pesantren berasal dari kata "santri", yang diberi awalan pe dan akhiran an menjadi pesantrian (pesantren) berarti tempat tinggal para santri, sedangkan santri adalah orang yang menuntut ilmu agama Islam. ${ }^{4}$ Pesantren di Jawa dan Madura sering disebut dengan pondok, sementara di Aceh corak pendidikan seperti itu disebut meunasah dan di Sumatera Barat disebut dengan surau. ${ }^{5}$ Pondok pesantren adalah tempat yang dihuni oleh para santri, hal ini menunjukkan bahwa ciri-ciri pondok pesantren sebagai sebuah lingkungan pendidikan integral dan memiliki sistem pendidikan yang sama dengan sistem yang dilakukan oleh akademi militer, artinya, adanya bangunan beranda, yang para penghuninya dapat mengambil pengalaman secara integral. ${ }^{6}$

Fungsi pondok pesantren tidak lepas dari hakikat dasarnya bahwa pesantren tumbuh dan berkembang berawal dari adanya masyarakat sebagai lembaga informal desa dalam bentuk yang sangat sederhana, oleh karena perkembangan dan kesejahteraan masyarakat tidak lepas dari kontribusi dan peran pondok pesantren dari segala bidang seperti pendidikan, ekonomi tentu juga agama yang mengarah pada nilai-nilai

4 Hanun Asrohah, Pelembagaan Pesantren Asal Usul Dan Perkembangan Pesantren Di Jawa (Jakarta: Departemin Agama RI, 2004). 20

5 Akhmad Faozan, "Pondok Pesantren Dan Pemberdayaan Ekonomi," Jurnal Ibda Vol.4 No.1 (n.d.): 88-102.

6 Marzuki Wahid, Pesantren Masa Depan Wacana Pemberdayaan Dan Transformasi Pesantren (Yogyakarta: Pustaka Hidayah, 2001). 13 
normatif, edukatif dan progresif. Adapun fungsi pondok pesantren sebagaimana berikut:

1. Pesantren Sebagai Lembaga Pendidikan

Dalam pengelolaannya pondok pesantren dalam pendidikan yang semula hanya bersifat sederhana kepada para santri maka berkebang secara reguler yang diikuti oleh masyarakat, hal ini pesantren pesantren dalam pengertiannya memberi pelajaran sebagai berikut: 1 . Pendidikan material adalah setiap santri diharapkan mampu menghatamkan dan membaca kitab kuning sesuai dengan target yang diharapkan dari segi materialnya tanpa diharapkan memahami lebih jauh terhadap isi yang tersirat di dalamnya, 2. Pendidikan immaterial adalah berbentuk suatu upaya perubahan sikap santri, agar menjadi pribadi tangguh dalam kehidupannya sehari-hari. ${ }^{7}$

2. Pesantren Sebagai Lembaga Dakwah

Melihat dari kiprah pesantren dalam melakukan dakwah dikalangan masyarakat dalam upaya melakukan kegiatan yang menumbuhkan kesadaran masyarakat dalam menekuni ajaran-ajaran agama secara konsisten sebagai pemeluk agama Islam. Kegiatan dakwah yang biasa dilakukan oleh pesantren pada masyarakat sebagai berikut:

a. Pembentukan kelompok pengajian bagi masyarakat.

Kegiatan pengajian yang dibentuk oleh pesantren merupakan media untuk menggembleng masyarakat dalam pengetahuan agama, bahkan juga tidak jarang sebagai mediasi dalam segala perkembangan yang terjadi dimasyarakat dalam segala bidang dari tatanan hidup sampai perkembangan ekonomi, oleh karenanya kegiatan

${ }^{7}$ M Bahri Ghazali, Pesantren Berwawasan Lingkungan (Jakarta: CV. Prasasti, 2002). 36 
pengajian ini dianggap sebagai alat komonikasi antara pondok pesantren dengan masyarakat.

b. Memadukan kegiatan dakwah dengan kegiatan masyarakat.

Pemaduan kegiatan ini berwujud seluruh aktifitas yang digemari masyarakat yang diselipkan fatwa agama dengan tujuan agar masyarakat sadar akan arti agama, seperti olahraga, diskusi atau kegiatan lain yang searti dengan kegiatan dakwah islamiyah. ${ }^{8}$

3. Pesantren Sebagai Lembaga Sosial

Pesantren sebagai lembaga sosial menunjukkan keterlibatan pesantren dalam menangani masalah sosial yang terjadi dimasyarakat, bukan saja terbatas dalam aspek kehidupan duniawi malainkan juga kehidupan ukhrawi, berupa bimbingan yang menurut sudjoko merupakan peran jasa terbesar pesantren terhadap masyarakat. Wujud nyata sebagai upaya penggarapan bidang sosial ekonomi adalah upaya peningkatan dan pengembangan ekonomi masyarakat dari tingkat paling lemah menjadi ekonomi sedang (menengah) bahkan meningkat sampai pada ekonomi mapan, termasuk dalam pengembangan ekonomi pesantren. Ini tidak langsung mendidik santri mandiri dalam membiayai dirinya sendiri melainkan masyarakat diharapkan mampu mengatur dirinya dan oleh dirinya sendiri dengan tingkat kemampuan ekonominya. ${ }^{9}$

4. Pesantren Sebagai Lembaga Produksi

Pesantren sebagai lembaga produksi agar bisa melanjutkan eksistensi dalam dunia usaha maka pesantren harus berinovasi dalam pengembangan produknya, jika hanya mengandalkan pasar tradisional yang dimiliki maka

${ }^{8}$ Ibid.38-39

${ }^{9}$ Ibid. 41 
perkembangannya akan cenderung stagnan. Langkah awal yang dilakukan adalah dengan mengefisienkan faktor produksi yang dimiliki yang kemudian mengembangkan diversifikasi produk dan tenaga kerja. Dengan demikian akan memunculkan efisiensi ekonomis. Sedangkan efisiensi ekonomis mengacu pada nilai output terhadap input, atau nilai sumber daya (faktor produksi) yang dipakai menghasilkan output tersebut. Pengukuran efisiensi ekonomis mensyaratkan nilai-nilai ditempatkan pada komoditi. ${ }^{10}$

5. Pesantren Sebagai Lembaga Konsumsi

Pesanten sebagai lembaga konsumsi ditunjukkan dari jumlah barang produksi yang diserap oleh pesantren baik oleh santri sebagai peserta didik maupun pesantren sebagai lembaga pendidikan, jika ditambahkan apabila pesantren memiliki usaha produksi, maka bahan baku usaha produksi ini juga akan menyerap barang produksi yang tidak sedikit. Jika di Jawa Timur terdapat 280.397 santri mukim putra dan 237.669 santri mukim putri, 213.647 santri kalong putra dan 15.232 santri kalong putri dengan jumlah total 946.945 santri dan masing masing santri setiap harinya mengkonsumsi secara rata-rata $\mathrm{Rp} 5.000$ maka dalam satu bulan mereka mengkonsumsi sebesar Rp 150.000. Ini artinya, total konsumsi para santri setiap bulannya adalah Rp 142.041.750.000; belum lagi untuk biaya operasional pesantren yang bisa 2-25 kali lebih besar dari junlah konsumsi santri. Ini berarti besarnya konsumsi pesantren sebagai lembaga pendidikan berkisar antara

10 Achmad Room Fitrianto, "Peran Pesantren Dalam Pengembangan Perekonomian Rakyat", Artikel (Diskusi Panel Penguatan Ekonomi Pesantren Dan Tantangan Perubahan Oleh Center For Islam And Democracy Studies," (Dosen Fakultas Syariah IAIN Sunan Ampel, Alumni Ekonomi Pembangunan Universitas Airlangga Surabaya) (n.d.): 5. 
284.083.500.000; - 3.551.043.750.000, ini berati merupakan serapan yang cukup besar terhadap total produksi yang dikeluarkan oleh industri. ${ }^{11}$

6. Sebagai Agen Perubahan

Fungsi terpenting pesantren adalah sebagai mesin penggerak perubahan di masyarakat. Sejak awal masuknya Islam ke Indonesia, pendidikan Islam merupakan kepentingan tinggi bagi kaum muslimin. Pada masa penjajahan pesantren sebagai agen perubahan sangat terasa, pesantren sebagai ujung tombak perjuangan bangsa yang menyediakan syuhada'-syuhada', pesantren sebagai penggerak perubahan masyarakat lambat laun tidak bisa di pungkiri, terutama setelah era 90 an dengan semakin di akomodirnya tokoh Islam oleh penguasa Orde Baru saat itu.

Menurut Suharitini dalam Halim et al., menjelaskan bahwa pondok pesantren dalam menjalankan fungsi-fungsi sosialnya dapat dikerucutkan pada empat fungsi utama, yaitu: a. Pusat pengkaderan pemikir-pemikir agama (Center of Excellence), b. Institusi yang mencetak sumber daya manusia (Human Resource), c. Lembaga yang mempunyai kekuatan melakukan pemberdayaan pada masyarakat (Agent of Development), dan d. Pondok pesantren sebagai bagian yang terlibat dalam proses perubahan sosial (Social Change). ${ }^{12}$

Adapun macam-macam Pesantren jika dilihat dari perkembangan pondok pesantren sebagai lembaga pendidik Islam mengalami perubahan yang sangat siknifikan dapat diraskan karena dampak kemajuan ilmu pengetahuan dan teknologi, namun hal ini tidak mengubah ciri khas pesantren

\footnotetext{
${ }^{11}$ Ibid.5

12 Marlina, "Potensi Pesantren Dalam Pengembangan Ekonomi Syariah," Jurnal Hukum Islam (JHI) Vol.12 No. (n.d.): 123.
} 
sebagai lembaga pendidikan Islam yang berkembang dan tumbuh dari masyarakat dan untuk masyarakat. Secara garis besar lembaga pesantren menurut Yacob dapat digolongkan menjadi dua tipologi, yaitu tipe pesantren salafi dan tipe pesantren khalafi.

1. Pesantren salafi yaitu pesantren yang tetap mempertahankan system (materi pengajaran) yang sumbernya kitab-kitab klasik Islam atau kitab dengan huruf Arab (gundul). Sistem sorogan (individual) menjadi sendi utama yang diterapkan. Pengetahuan non agama tidak diajarkan.

2. Pesantren khalafi yaitu system pesantren yang menerapkan system madrasah, yaitu pengajaran secara klasikal, dan memasukkan pengetahuan umum dan bahasa non-/Arab dalam kurikulum, serta tak lupa menambahkan dengan berbagai keterampilan.

\section{Konsep Pengembangan dan Pemberdayaan Masyarakat}

Pengembangan masyarakat adalah salah satu metode kegiatan sosial yang mempunyai tujuan untuk memperbaiki kualitas kehidupan masyarakat melalui pendayagunaan sumber-sumber yang ada pada masyarakat serta menekankan pada prinsip partisipasi sosial. ${ }^{13}$ Pengembangan masyarakat meliputi berbagai pelayanan sosial yang berbasis masyarakat mulai dari pelayanan preventif untuk mencegak anak-anak terlantar atau diperlakukan salah sampai pelanan kuratif dan pengembangan untuk keluarga yang berpendapatan rendah. Adapun pengembangan masyarakat sebagai berikut:

1. Konsep dan cakupan pengembangan masyarakat

Dalam usaha menggambarkan hubungan antara pengorganisasian dan pengembangan masyarakat, menyatakan ada lima prinsip dasar yang amat penting bagi

13 Edi Suharto, Membangun Masyarakat, Memberdayakan Rakyat, Kajian Strategis Sosial \& Pekerjaan Sosial(Bandung: Reflika Aditama, 2017).37 
mereka yang berminat pada pengorganisasian masyarakat ataupun pengembangan masyarakat. Prinsip-prinsip tersebut adalah:

a. Penekanan terhadap pentingnya kesatuan kehidupan masyarakat dan hal yang terkait dengan hal tersebut dimana pengorganisasian ataupun pengembangan masyarakat harus dilakukan dengan mempertimbangkan keseluruhan kehidupan masyarakat, dan tidak dilakukan hanya untuk segmen tertentu dalam kehidupan masyarakat, seperti halnya untuk aspek kesehatan, rekreasi, ataupun kesejahteraan dalam arti sempit saja.

b. Perlu adanya kedekatan antar tim dalam pengembangan masyarakat, dimana tidak hanya menekankan pada pendekatan multiprofesi, tetapi juga multilapisan profesi, karena disini diperlukan adanya keterlibatan layanan yang subprofesional, selain layanan yang professional.

c. Kebutuhan akan adanya community worker yang serba bisa pada wilayah pedesaan, dimana petugas harus mampu bekerja pada berbagai pekerjaan yang berbeda.

d. Pentingnya pemahaman akan pola budaya masyarakat lokal. Lebih jauh lagi, para petugas haruslah benar-benar tulus ingin mengembangkan masyarakat yang ada, bukan sekedar memperkenalkan ataupun membawa teknologi yang baru kemasyarakat sasaran.

e. Adanya prinsip kemandirian yang menjadi prinsip utama dalam pengembangan masyarakat. Pengembangan masyarakat harus dilaksanakan bersama masyarakat dan bukan sekedar untuk masyarakat. ${ }^{14}$

2. Model-Model Pengembangan Masyarakat

14 Isbandi Rukminto, Intervensi Komunitas \& Pengembangan Masyarakat (Jakarta: Raja Grafindo Persada, 2008).160-161 
Dalam mengembangkan masyarakat Jack Rohman menjelaskan bahwa ada tiga model dalam memahami konsepsi pengembangan masyarakat yaitu;

a. Pengembangan masyarakat lokal (locality development) adalah proses yang ditujuakan untuk menciptakan kemajuan sosial dan ekonomi bagi masyarakat melalui partisipasi aktif serta inisiatif masyarakat itu sendiri, serta masyarakat tidak dipandang sebagai klien melainkan dianggap sebagai masyarakat yang memiliki potensi.

b. Perencanaan sosial (social planing) adalah proses pragmatis untuk menentukan keputusan dan menetapkan tindakan dalam mencari jalan keluar dari masalah sosial seperti kemiskinan, pengangguran, kenakalan remaja, kesehatan masyarakat dan lain sebagainya, dalam hal ini lebih berorientasi pada tujun tugas (task goal).

c. Aksi sosial (social action) adalah kegiatan yang memiliki tujuan utama sebagai perubahan-perubahan fundamental dalam kelembagaan dan struktur masyarakat melalui proses pendistribusian kekuasaan (distribution of power), sumber (distribution of resources) dan pengambilan keputusan (distribution of dicision making). ${ }^{15}$

3. Proses Pengembangan Masyarakat

Pendekatan bottom-up, perubahan dari bawah dan partisipasi merupakan prinsip fundamental dalam pengembangan masyarakat. Tidak hanya pada partisipasi proses itu berpijak, melainkan juga pada persoalan hasil dan tujuan. adapun penekanan pengembangan masyarakat yang diarahkan pada proses bukan pada hasil merupakan penekanan yang sama radikalnya pada perubahan dan

15 Suharto, Membangun Masyarakat, Memberdayakan Rakyat, Kajian Strategis Sosial \& Pekerjaan Sosial.42-44 
partisipasi dari bawah, untuk proses-proses pengembangan masyarakat tersebut sebagai: a. Integritas Proses, b. Peningkatan Kesadaran, c. Langkah Pengembangan, d. Konsensus. ${ }^{16}$

Adapun pemberdayaan Masyarakat Secara konseptual, pemberdayaan atau pemberkuasaan (empowerment), berasal dari kata power, oleh karenanya ide ide utama pemberdayaan bersentuhan dengan konsep mengenai kekuasaan. Kekuasaan sering kali dikaitkan dengan kemampuan seseorang untuk membuat orang lain melakukan apa yang diinginkan.

Pemberdayaan menunjuk pada kemampuan orang atau kelompok yang rentan dan lemah sehingga memiliki kekuatan atau kemampuan dalam tiga hal yaitu: a). Memenuhi kebutuhan dasarnya sehingga mereka memiliki kebebasan (freedom), dalam artian bukan hanya bebas dalam berpendapat tapi juga bebas dari kelaparan, kebodohan, dan kesakitan, b). Menjangkau sumber-sumber produktif yang memungkinkan dapat meningkatkan pendapatannya, memperoleh barangbarang dan jasa-jasa yang dibutuhkan, dan c). Berpartisipasi dalam proses pembangunan dan keputusan-keputusan yang mempengaruhi mereka. ${ }^{17}$

\section{Kegiatan Pesantren dalam meningkatkan moto kewirausahaan (entrepreneurship)}

Dalam upaya meningkatkan dan mengembangkan ekonomi masyarakat yang menjadi kegiatan pengembangan program Pondok Pesantren Miftahul Ulum Panyeppen Pamekasan sebagai lembaga sosial, tentu harus didukung dengan kegiatan-kegiatan yang mampu membangun jiwa dan moto kewirausahaan baik pada santri, pengelola ekonomi

\footnotetext{
16 Jim Ife and Frank Tesoriero, Community Development: Alternatif Pengembanga Masyarakat Di Era Globalisasi (Yogyakarta: Pustaka Pelajar, 2008).335-362

17 Suharto, Membangun Masyarakat, Memberdayakan Rakyat, Kajian Strategis Sosial \& Pekerjaan Sosial.58
} 
(karyawan) maupun masyarakat sehingga cita-cita pesantren dalam upaya mengembangkan ekonominya dapat berjalan dan sesuai harapan. Adapun kegiatan-kegiatan pondok pesantren Miftahul Ulum Panyeppen dalam meningkatkan moto kewirausahaan sebagaimana berikut;

1. Pelatihan-pelatihan

Pelatihan pengembangan moto pada karyawan seperti diklat keuangan shariah, pengikatan agunan, marketing, leadership serta uji kompetensi SKKNI dilaksanakan setiap enam bulan satu kali secara berkala, adapun pada masyarakat memberi pelatihan kewirausahaan melalui pendekatan persuasif, pengajian-pengajian, perkumpulan ibu-ibu untuk lebih kreatif, salah satunya dengan mengajak masyarakat sumbangan bersama membangun lembaga keuangan dan penyediaan modal usaha. ${ }^{18}$

2. Pengiriman delegasi

Dalam meningkatkan moto dan membangun jiwa santri menjadi entrepreneurship, Pondok Pesantren Miftahul Ulum Panyeppen juga sering mengirimkan delegasi untuk mengikuti training of trainer, pelatihan perkembangan ekonomi yang diadakan oleh lembaga-lembaga keuangan shariah atau perbankan shariah ke berbagai wilayah seperti Pacet, Surabaya dan lain-lain khususnya di Jawa timur.

3. Studi banding/kerjasama

Salah satu kegiatan Pondok Pesantren Miftahul Ulum Panyeppen dalam mengebangkan moto kewirausahaan adalah studi banding dan kerjasama dengan lembaga yang maju dalam mengelola dan mengembangkan ekonomi

\footnotetext{
${ }^{18}$ Moh. Bahri, Manajer BMT Pusat, Wawancara, 12 April 2018.
} 
ummat yang berbasis shariah seperti Pondok Pesantren Sidogiri Kraton Pasuruan. ${ }^{19}$

\section{Potensi Pondok Pesantren Miftahul Ulum Panyeppen Pamekasan}

Pondok Pesantren Miftahul Ulum Panyeppen mempunyai potensi untuk dikembangkan sehingga pada akhirnya dapat membantu kegiatan dan aktifitas yang dilakukan oleh pesantren utamanya dalam mengembangkan ekonomi masyarakat. Adanya pendidikan formal (SMP, SMA, SMK dan STAIMU) dengan beberapa jurusan dimiliki, Pondok Pesantren Miftahul Ulum Panyeppen mempunyai potensi yang bisa diharapkan mampu untuk melatih dan mendidik para santri dengan berbagai disiplin ilmu sehingga santri nantinya dapat membantu mengembangkan ekonomi masyarakat dengan pelatihan-pelatihan dan pendidikan yang telah didapatkan dari Pondok Pesantren Miftahul Ulum Panyeppen Pamekasan, seperti alumni Sekolah Menengah Kejuruan, jurusan Teknik Komputer dan Jaringan, mereka bisa menjadi teknisi dan membuka service komputer, jurusan Multi Media mereka dilatih yang nantinya bisa membuka studio foto, begitu pula yang jurusan Otomotif mereka dilatih untuk bisa membuka bengkel. Begitu juga dari lulusan STAI Miftahul Ulum utamanya dari Program Studi Ekonomi Shariah mereka diharapkan mampu menjadi pilar dalam gerekan ekonomi umat yang berbasis shariah seperti bekerja di lembaga keuangan shariah atau perbankan shariah, walaupun dari jurusan yang lain memiliki spesifikasi masing-masing. ${ }^{20}$ Selain lembaga di atas, ada beberapa potensi yang dimilki pesantren, yaitu;

1. Santri

\footnotetext{
${ }^{19}$ Muhdlar Abdullah, Ketua Yayasan Al-Miftah, Wawancara, Pamekasan, 16 Maret 2018.

${ }^{20}$ Muhdlar Abdullah, Ketua Yayasan Al-Miftah, Wawancara, Pamekasan, 16 Maret 2018.
} 
Santri adalah peserta didik yang dimiliki oleh Pondok Pesantren Miftahul Ulum Panyeppen Pamekasan yang dititipkan oleh orang tuanya pada pesantren untuk mempelajari beberapa kegiatan pendidikan agama Islam, dalam hal ini Pondok Pesantren Panyeppen membagi tiga (3) bagian yaitu;

a. Al-Badar

Santri yang mukim dan menetap di asrama yang sudah disediakan oleh pondok pesantren yang disebabkan karena jarak antara pondok pesantren dan rumahnya yang relatif jauh baik dari Jawa maupun luar Jawa, atau anak sekitar pesantren tetapi mukim di pesantren dan harus mengikuti kegiatan selama 24 jam sampai pada hari libur pesantren. Nama Al-badar sendiri disematkan pada santri mukim untuk mengenang jasa dari salah satu pendiri Pondok Pesantren Miftahul Ulum Panyeppen Pamekasan yaitu Romo KH. Badruddin Muddatstsir.

b. Al-Nashar

Santri kalong (colok) atau santri yang berasal dari sekitar Pondok Pesantren Miftahul Ulum Panyeppen Pamekasan yang tidak menetap di asrama yang sudah disediakan oleh posantren, mereka hanya mengikuti sekolah diniyah, umumiyah dan Qur'aniyah dan tidak dituntut tetapi dianjurkan untuk mengikuti semua kegiatan pondok pesantren. Nama Al-Nashar ini diberikan pada santri yang tidak mukim di pesantren untuk mengenang jasa dari salah satu pendiri Pondok Pesantren Miftahul Ulum Panyeppen Pamekasan yaitu Romo KH. Nashruddin bin Itsbat. $^{21}$

c. Siswa dan Mahasiswa

${ }^{21}$ Bahrudin Habibi, Koordinator Pengurus, Wawancara, Pamekasan, 21 Pebruari 2018 
Santri dari luar Pondok Pesantren Miftahul Ulum Panyeppen Pamekasan yang datang dari beberapa wilayah yang hanya mengikuti sekolah formal (umum) yang sesuai dengan jenjang pendidikannya masingmasing dan kegiatan mereka hanya dari pagi sampai siang hari.

\section{Alumni}

Santri yang sudah keluar dari Pondok Pesantren Miftahul Ulum Panyeppen Pamekasan baik keluarnya karena sudah lulus maupun keluar karena faktor lain seperti kekurangan biaya, dibutuhkan keluarga dan sebagainya. Alumni Pondok Pesantren Miftahul Ulum Panyeppen Pamekasan dibentuk organisasi untuk komonikasi antara pesantren dan alumni yang barada dibawah naungan yayasan Al-miftah dan diberi nama:

a. IKBAS

Ikatan Keluaga Besar Alumni dan Simpatisan Pondok Pesantren Miftahul Ulum Panyeppen Pamekasan (IKBAS) adalah organisasi yang menghipun semua alumni pesantren yang mengkomonikasikan semua kegiatan pesantren yang berkaitan dengan alumni dan masyarakat dari berbagai sektor, baik pendidikan, dakwah sosial dan ekonomi. Adapun jumlah alumni yang terdata sampai saat ini mencapai 12.335 (Dua belas ribu tiga ratus tiga puluh lima) orang. ${ }^{22}$

b. BADKOM

Badan Komonikasi (BADKOM) Pondok Pesantren Miftahul Ulum Panyeppen Pamekasan yang menjaga dan mengawasi ustadz tugas dan da'i yang dikirim oleh pesantren ke lembaga-lembaga pengambil guru tugas dan

${ }^{22}$ Badrut Tamam, Bendahara IKBAS, Wawancara, Pamekasan, 17 April 2018. 
menjalani dakwahnya pada masyarakat. Pengurus BADKOM ini diambilkan dari alumni senior yang mempunyai kapabilitas dan kredibilitas tinggi dari semua sisi karena bersentuhan langsung dengan masyarakat yang sebagian masih belum tahu tentang keadaan pondok pesantren.

3. Simpatisan atau Masyarakat

Sekelompok warga yang tidak pernah mondok atau belajar langsung di Pondok Pesantren Miftahul Ulum Panyeppen Pamekasan tetapi mempunyai loyalitas tinggi terhadap pondok pesantren yang terhimpun dalam beberapa kegiatan, sebagaimana berikut;

a. Pengajian untuk Ibu-ibu. Pengajaran tentang budaya Islami, pengetahuan tentang ilmu agama dan hal-halyang ada kaitannya dengan masalah perempuan, yang disampaikan oleh asatidz Pondok Pesantren Miftahul Ulum Panyeppen Pamekasan setiap hari jum'at.

b. Yasinan. Kegiatan rutin yang diadakan oleh Pondok Pesantren Miftahul Ulum Panyeppen Pamekasan untuk masyarakat dan simpatisan yang diadakan setiap malam selasa dan malam jum'at.

c. Pengajian Kitab Kuning. Kegiatan bulanan yang dilaksanakan di beberapa masjid di berbagai wilayah yang diasuh langsung oleh pengasuh Pondok Pesantren Miftahul Ulum Panyeppen Pamekasan.

4. Madrasah Ranting dan Madrasah Afiliasi.

Madrasah ranting adalah madrasah atau lembaga pendidikan yang kurikulumnya menyesuaikan dan sama dengan kurikulum Pondok Pesantren Miftahul Ulum Panyeppen Pamekasan serta pelaksanaan kegiatannya disetarakan dengan pondok pesantren dan semua kebutuhannya didistribusikan dari pondok pesantren seperti kitab dan kebutuhan yang lain. Adapun madrasah 
afiliasi adalah lembaga dan madrasah yang hanya mengambil ustadz tugas pada Pondok Pesantren Miftahul Ulum Panyeppen Pamekasan, sedangkan kurikulumnya tidak sama dengan kurikulum Pondok Pesantren Miftahul Ulum Panyeppen Pamekasan.

\section{Peran dan Aktifitas Pondok Pesantren Miftahul Ulum Panyeppen Pamekasan dan Yayasan Al-Miftah dalam Mengembangkan Ekonomi Masyarakat}

Pengasuh Pesantren (Romo KH. Muddatstsir Badruddin) dan Ketua Yayasan Al-Miftah di samping bermasyarakat dan mumpuni di bidang managemen umum, juga mempunyai skill di bidang usaha ekonomi, semua berkat bimbingan yang diperolehnya selama belajar di Pondok Pesantren Sidogiri Pasuruan selama 11 tahun (1959-1960 sampai 1979-1971). Sejak tahun 1961-1968, Romo KH. Muddatstsir Badruddin dibimbing langsung oleh Ketua Umum Pengurus Pondok Pesantren Sidogiri (waktu itu K A. Sa'dullah Nawawi), denngan tugas menangani Ketua merangkap Manager Koperasi Pesantren Sidogiri.

KH. Muddatstsir Badruddin (sejak 1973) setelah 2 (dua) tahun mengasuh Pondok Pesantren Miftahul Ulum Panyepen, beliau menjalankan beberapa usaha sabagai peningkatan sumber dana untuk mendanai kegiatan pendidikan yang semakin meningkat, karena beliau memahami, bahwa keberlangsungan Pondok Pesantren Miftahul Ulum Panyeppen Pamekasan dan Yayasan dalam menjalankan program pendidikan, dakwah dan kemasyarakatan yang menjadi tugas besar tentu harus ditopang dengan ekonomi yang mapan, sebagai lembaga institusi tentu harus memiliki sumber-sember ekonomi yang mempuni upaya dalam mengembangkan ekonomi pesantren dan pengembangan ekonomi masyarakat.

Edi Suharto dalam bukunya menjelaskan bahwa Secara garis besar pengembangan masyarakat dapat diartikan dalam dua konsep yaitu masyarakat sebagai tempat bersama dan masyarakat sebagai kepentingan bersama, dari pendapat 
tersebut sudah jelas bahwa pesantren dan perannya dalam mengembangkan ekonomi masyarakat harus dibuktikan dengan aktifitas-aktifitas yang nyata dan mengikat sehingga dapat dikembangkan bersama oleh pesantren dan masyarakat, dengan keterlibatan masyarakat dalam hal ini maka pesantren dapat dengan baik mengetahui seberapa besar aktifitas pesantren tersebut dalam mengembangkan ekonomi masyarakat.

Ini juga didukung oleh pendapat Dunham yang mendefinisikan pengembangan masyarakat sebagai berbagai upaya yang terorganisir yang dilakukan guna meningkatkan kondisi kehidupan masyarakat, terutama melalui usaha yang komperatif dan mengembangkan kemandirian dari masyarakat pedesaan, tetapi hal tersebut dilakukan dengan bantuan teknis dari pemerintah ataupun lembaga -lembaga sukarela. Demikian Pondok Pesantren Miftahul Ulum Panyeppen Pamekasan juga memiliki beberapa peran dan aktifitas perekonomian yang nyata upaya dalam mengembangkan ekonomi masyarakat. Adapun bentuk-bentuk usaha ekonomi yang dikembangkan oleh Yayasan Al-miftah sebagai berikut;

1. Usaha Internal Pondok Pesantren

Adapun unit usaha internal pengembangan ekonomi pondok pesantren yang berada dibawah tanggungjawab Yayasan sebagaimana berikut;

a. Unit usaha produktif

Usaha produktif yang dilakukan oleh Yayasan Al-Miftah selama ini baik yang sudah berjalan atau sedang berjalan ada empat (4) macam, sebegaimana berikut;

1) Unit Catering Santri

Yayasan Al-MIftah mengelola Unit Catering Santri sebagai lembaga yang menjadi penyedia konsumsi santri dan guru pondok pesantren, hal ini merupakan usaha produktif pesantren dalam mengembangkan ekonomi masyarakat, adapun bahan baku produksi disediakan oleh masyarakat dan keluarga pesantren. 
Pondok Pesantren memiliki 1703 santri aktif dan 550 santri kalong dengan jumlah total 2.253 (dua ribu dua ratus lima puluh tiga) santri dan masing-masing santri aktif harus membayar biaya konsumsi Rp. 180.000/bulan dengan dua kali makan setiap hari maka dalam satu bulan dapat terkumpul Rp. 306.540.000, sedangkan santri kalong masing-masing santri setiap harinya mengkonsumsi secara rata-rata Rp. 15.000/hari maka dalam satu bulan dapat terkumpul Rp. 247. 500.000 sehingga bisa di total dalam satu bulan pemasukan UCS sebesar Rp. 554. 040.000/bulan dengan jumlah pengeluaran setiap bulannya Rp. 510.435.000/bulan dengan usaha ini dapat keuntungan sebesar Rp. 43. 605.000.23

2) Pertokoan/ritel

Pertokoan adalah salah satu aktivitas yang dijalankan oleh Yayasan Al-miftah dalam upaya mengembangkan ekonomi pondok pesantren dan juga ekonomi masyarakat karena dengan hal ini dapat memberi lapangan pekerjaan dan memudahkan masyarakat untuk memenuhi kebutuhannya dengan harga standart, yang dikenal dengan nama KOIM Swalayan. KOIM Swalayan ini sudah beridiri di pasar Tlengir Desa Bira Tengah Sokobanah, pasar Karang Penang Sampang dan Desa Poto'an Laok Palengaan Pamekasan.

Beberapa pertokoan yang tersebar dibeberapa daerah tersebut menyediakan beberapa kebutuhan santri dan masyarakat seperti, bahan-bahan sembako, pakaian,

23 Taufiqur Rohman, Ketua Unit Catering Santri, Wawancara, Pamekasan, 26 Pebruari 2018. 
aksesoris, alat-alat mandi, alat-alat sekolah lainnya dan juga kebutuhan masyarakat yang lain.

H. Ismail Madani manajer KOIM swalayan yang berada di Pasar Tlengir Sokobanah Sampang, dia mengakui bahwa keberadaan swalayan milik Yayasan Al-miftah ini, sangat membantu memudahkan masyarakat mendapatkan kebutuhannya mulai dari pakaian, aksesoris, dan kebutuhan yang lain.

Menurut penjelasan $H$. Ismail, keberadaan KOIM Swalayan juga sangat membantu terhadap masyarakat dalam mengurangi pengangguran dan meningkatkan kesejahteraan ekonomi masyarakat karena yang menjadi karyawan adalah alumni potesial dan masyarakat tidak mampu. Ini juga mendapat respon positif dari masyarakat tentang keberadaan swalayan ini, hal tersebut dilihat dari omset setiap harinya mencapai Rp. 18.500.000-Rp. 20.000.000/hari, apalabila dikalkulasi perbulannya tidak kurang dari Rp. 455.000.000-Rp. 520.000.000/bulan dengan 15\% laba dan keuntungan bersih yang dimiliki oleh KOIM Mawaddah, dan tidak menutup kemungkinan akan semakin meningkat. ${ }^{24}$

Adapun KOIM Swalayan yang berada di Pasar karangpenang juga mendapatkan omset yang fantastis walau masih di bawah pendapatan yang didapat dari KOIM Swalayan Tlengir yaitu sekitar Rp. 12.000.000Rp.15.000.000/hari maka dapat dijumlahkan pemasukan KOIM Swalayan Karangpenag ini mencapai Rp. 360.000.000-Rp. 450.000.000/bulan dengan 15\%

24 Ismail, Manajer KOIM Swalyan Tlengir, Wawancara, Sampang, 06 Maret 2018. 
laba bersih, ini disampaikan oleh Ust. Khozairi selaku manajer KOIM Swalayan Karangpenang. ${ }^{25}$

3) Peternakan

Sejak tahun 2013 Yayasan Al-Miftah menjalankan usaha ternak ayam petelur yang berada di Desa Poto'an Laok Pamekasan dan dikelola oleh masyarakat. Ini melihat dari banyaknya permintaan masyarakat karena ini merupakan kebutuhan masyarakat seharihari, Moh. Syawal penanggung jawab usaha ini, menjelaskan bahwa sebelum ayam petelur ini pesantren mengelola ayam horen (putih) namun hanya berjalan dua tahun saja karena melihat masyarakat pada waktu itu juga banyak yang menglolanya, sehingga ayam petelur ini sebagai alternatif, adapun ayam yang dikelolanya sebanyak 1.000 ekor dan dalam setiap harinya tidak kurang dari 50-55 kg telor dengan harga Rp.20.000/kg, jadi kalau dikalkulasi dalam setiap harinya bisa mendapatkan hasil sebesar Rp. 1.000.000Rp. 1.100.000.

Harga di atas bukan menjadi harga tetap karena harga selalu mengikuti pasar dan seberapa besar kebutuhan masyarakat seperti pada bulan Maulid dan Romadlan biasanya permintaan masyarakat meningkat sementara penyedian telor berkurang sehingga sangat mempengaruhi terhadapa peningkatan harga telor yang melambung, maka pendapatannya juga sangat meninggi. ${ }^{26}$

4) Lembaga Keuangan Syariah

${ }^{25}$ Khozairi, Manajer KOIM Swalyan Karangpenang, Wawancara, Sampang, 10 Maret 2018.

${ }^{26}$ Moh. Syawal, Penjaga Ayam Petelur, Wawancara, Pamekasan, 11 Maret 2018 
Yayasan Al-Miftah mengelola lembaga keuangan shariah untuk menunjang pengembangan ekonomi masyarakat yang bebasis shariah, bernama koperasi Al-Iqtishod Lil Muamalah Mawaddah Shariah Jawa Timur disingkat Koperasi KOIM Mawaddah adalah salah satu usaha ekonomi Pondok Pesantren Miftahul Ulum Panyeppen Pamekasan yang beranggotakan alumni, wali santri, santri dan simpatisan/masyarakat. Selain itu juga terdapat BMT Mawaddah, dalam rekrutmen karyawan, BMT Mawaddah mengambil alumni dan simpatisan/masyarakat tidak mampu yang mempunyai komitmen, etos kerja tinggi dan amanah sebagai karyawan, diawali dengan pengenalan kerja yang akan menjadi tanggung jawabnya melalui pelatihan, training dan percobaan secara bergantian di masing-masing sektor baik costumer service, teller, marketing atau hal-hal lain, ini dilakukan untuk melihat dan mengetahui kelayakan, kemampuan dan kelebihan calon karyawan sehingga dengan proses itu, pihak BMT mawaddah dengan mudah menempatkan karyawan sesuai dengan kemampuannya. ${ }^{27}$

BMT Mawaddah sudah bisa dikatakan sesuai dengan ekpektasi masyarakat hal ini dapat dibuktikan dengan tingkat kepercayaan masyarakat terhadap BMT Mawaddah yang berada dibawah naungan KOIM Mawaddah ini yang semakin meningkat dari tahun ke tahun, hal ini dapat kita lihat dari sisa hasil usaha (SHU) yang dari tahun ketahun juga meningkat dan asset yang dimilikinya. Peneliti mengambil sample SHU tiga tahun terakhir dari tahun 2015-2017, yaitu BMT

${ }^{27}$ Thoif Wijaya, Ketua KOIM, Wawancara, Pamekasan 5 April 2018. 
Mawaddah pada Tahun 2015 memiliki SHU sebesar Rp. 2. 495. 312. 549. Pada tahun 2016 memiliki SHU sebesar Rp. 3. 415. 246. 964 dan pada tahun 2017 meningkat menjadi Rp. 4. 393. 306. 658. Maka persentase jasa anggota terhadap simpanan anggota pada tahun 2017 adalah $20.18 \%$.

b. Unit usaha dibidang jasa

1) Mesin Foto Copy

Penyedian mesin foto copy sebagai usaha riil dibidang jasa yang dikelola oleh KOIM, penyediaan mesin foto copy ini hanya berada di kawasan pondok pesantren saja yang konsumen dari kalangan santri, mahasiswa dan masyarakat. Usaha ini relatif maju walaupun ada waktu-waktu tertentu seperti hari kamis-sabtu karena hari itu termasuk hari aktif mahasiswa maka pendapatannya meningkat.

Untuk meningkatkan pendapatannya, pengelolaan mesin foto copy ini mengadakan kerjasama dengan lembaga sekitar utamanya dengan lembaga yang ada dilingkungan pondok pesantren dengan cara memberikan fee secukupnya dan kerjasama secara intent, hal ini dapat dibuktikan pendapatan setiap harinya yang mencapai kisaran Rp. 850.000-Rp. 1. 250.000/hari dan system penyetoran uang pendapatannya berpusat pada BMT Mawaddah satu minggu sekali.

2) Mesin Cuci Pakaian (Loudry)

Salah satu kegiatan ekonomi Pondok Pesantren Miftahul Ulum Panyeppen adalah penyedian mesin cuci pakaian (loudry) untuk santri yang dikelola oleh masyarakat dengan sistem gaji perbulan, dari usaha ini pondok pesantren mendapatkan pemasukan yang relatif besar yaitu mencapai rata-rata Rp. 4. 320.000;

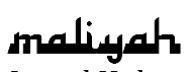


setelah dikurangi gaji penjaga mesin cuci tersebut sebesar Rp. 750.000/bulan. Dengan demikian pemasukan dari mesin cuci dapat dipastikan mencapai rata-rata Rp. 5. 070. 000/bulan, jadi dalam satu tahun mencapai Rp. 60.840.000/tahun. ${ }^{28}$

2. Usaha Eksternal Pondok Pesantren.

Usaha pengembangan ekonomi masyarakat eksternal pesantren adalah jenis usaha yang dilakukan oleh masyarakat sekitar pesantren dengan karakter sebagai suplier makanan ringan kepada santri di pesantren Miftahul Ulum Panyeppen. Makanan ringan tersebut dititipkan di kantin dan koperasi yang ada di dalam pesantren, atau di kios-kios yang sudah disiapkan oleh pondok dengan dititipkan kepada penjaga khusus yang sudah diangkat oleh pesantren, dengan imbalan setiap satu bungkus nasi mendapatkan Rp. 500.

Menurut keterangan Halimah, salah seorang penjual nasi bungkus menjelaskan, bahwa rata-rata dari harga barang yang ditentukan oleh pedagang, pihak pesantren mendapatkan keuntungan $5 \%$ atau mendapatkan keuntungan Rp. 500/bungkus dari harga asal. Apabila nasi bungkus yang dititipkan mencapai 100 bungkus dan habis sekaligus, berarti pihak pesantren akan mendapatkan keuntungan Rp. 50.000 untuk jenis dagangan nasi bungkus dan gorengan, adapun pada jenis dagangan kerupuk, kacang dan lainnya dengan sistem dibeli oleh pihak pesanten. ${ }^{29}$ Usaha tersebut menjadi sumber mata pencaharian mereka

\footnotetext{
${ }^{28}$ Bahrudin Habibi, Koordinator Pengurus, Wawancara, Pamekasan, 21 Pebruari 2018.

${ }^{29}$ Bahrudin Habibi, Koordinator Pengurus, Wawancara, Pamekasan, 21 Pebruari 2018
} 
sehari-hari, sama juga dengan masyarakat yang mempunyai jenis usaha permanen di sekitar pesantren. ${ }^{30}$

Selain kegiatan pengembangan ekonomi masyarakat di atas, Pondok Pesantren Mifatahul Ulum Panyeppen dalam pemberdayaan dan pengembangan ekonomi masyarakat juga mempunyai program pemberian modal usaha melalu akad qard al-hasan. Program ini merupakan salah satu program yang bertujuan untuk mengembangkan ekonomi dan kesejahteraan masyarakat miskin melalui dana zakat.

Qard al-hasan merupakan salah satu akad yang memiliki angsuran ringan dan tanpa potongan sesuai dengan kesepakatan kedua belah pihak, atau dengan menggunakan akad hibah. Ini untuk membuka akses keuangan kepada masyarakat kurang mampu, sedangkan pendanaan program ini dihimpun dari dana zakat yang didistribusikan khusus untuk program pengembangan ekonomi masyarakat. ${ }^{31}$

Tabel dana zakat yang terhimpun dalam upaya pengembangan ekonomi masyarakat ${ }^{32}$

\begin{tabular}{|l|l|c|c|}
\hline No & \multicolumn{1}{|c|}{ Tahun } & Dana Terhimpun & Realisasi \\
\hline 1 & 2015 & Rp. 100.325 .476 .000 & Rp. 95.350 .000 \\
\hline 2 & 2016 & Rp. 130.496 .382 .000 & Rp. 109.500 .000 \\
\hline 3 & 2017 & Rp. 156.253 .958 .000 & Rp. 143.150 .000 \\
\hline
\end{tabular}

Program ini diperuntukkan kepada mustahik/masyarakat tidak mampu yang sudah memliki usaha mikro atau hendak membuka usaha mikro. Dengan program ini diharapkan mampu memberikan kesejahteraan masyarakat dalam

\footnotetext{
${ }^{30}$ Ibid.

31 Thoif Wijaya, Ketua KOIM, Wawancara, Pamekasan 5 April 2018.

${ }^{32}$ Buku RAT, Laporan......, 16.
} 
mengembangkan ekonominya, tentu dengan pemberian pelatihan kewirausahaan dan pengawasan yang intensif dari Pondok Pesantren Miftahul Ulum Panyeppen Pamekasan yang bersifat berkala dan berkesinambungan. ${ }^{33}$

\section{Analisis potensi Pondok Pesantren Miftahul Ulum Panyeppen Pamekasan dalam mengembangkan ekonomi masyarakat}

Sebagaimana teori yang disampaikan oleh Suhartini bahwa pesantren sebagai institusi yang mencetak sumber daya manusia (Human Resource) penggerak terhadap semua aktifitas yang akan dikembangkan oleh pesantren baik pendidikan, dakwah dan ekonominya, maka Pondok Pesantren Miftahul Ulum Panyeppen juga mempunyai potensi yang sama dan dimiliki untuk membantu kegiatan dan aktifitas yang dilakukan oleh pesantren utamanya dalam mengembangkan ekonomi masyarakat. Adapun potensi tersebut sebagaimana berikut;

1. Pendidikan Formal

Pendidikan formal dari berbagai jenjang pendidikan yang mencapai 2.132 siswa dan mahasiswa dengan beberapa jurusan yang dimiliki seperti jurusan otomotif, tata busana, multi media, teknik computer dan jaringan, Ekonomi Shariah, AS dan lain-lain merupakan salah satu potensi yang harus dikembangkan yang nantinya para alumni terbentuk menjadi sumber daya manusia (SDM) yang siap membantu dalam mengembangkan ekonomi pesantren dan ekonomi masyarakatan begitu juga menjadi manusia entepreneship.

2. Santri

Santri adalah peserta didik yang dimiliki oleh Pondok Pesantren Miftahul Ulum Panyeppen Pamekasan yang dititipkan oleh orang tuanya pada pesantren untuk

\footnotetext{
33 Thoif Wijaya, Ketua KOIM, Wawancara, Pamekasan 5 April 2018.
} 
mempelajari beberapa kegiatan pendidikan agama Islam dan pendidikan umumiyah, dalam hal ini Pondok Pesantren Panyeppen membagi tiga (3) bagian yaitu al-badar, alnashar dan siswa/mahasiswa.

3. Alumni

Santri yang sudah keluar dari Pondok Pesantren Miftahul Ulum Panyeppen Pamekasan baik keluarnya karena sudah lulus maupun keluar karena faktor lain seperti kekurangan biaya, dibutuhkan keluarga dan sebagainya. hal ini, alumni Pondok Pesantren Miftahul Ulum Panyeppen Pamekasan dibentuk suatu wadah komonikasi antara pesantren dan alumni yang barada dibawah naungan yayasan Al-miftah dan diberi nama IKBAS, dan BADKOM

4. Simpatisan/masyarakat

Sekelompok warga yang tidak pernah mondok atau belajar langsung di Pondok Pesantren Miftahul Ulum Panyeppen Pamekasan tetapi mempunyai loyalitas tinggi terhadap pondok pesantren. hal ini terhimpun dalam beberapa kegiatan

5. Madrasah Ranting/afiliasi

Madrasah rantig adalah madrasah atau lembaga pendidikan yang kurikulumnya menyesuaikan dan sama dengan kurikulum Pondok Pesantren Miftahul Ulum Panyeppen Pamekasan serta pelaksanaan kegiatannya disetarakan dengan pondok pesantren dan semua kebutuhannya didistribusikan dari pondok pesantren seperti kitab dan kebutuhan yang lain. Adapun madrasah afiliasi adalah lembaga dan madrasah yang hanya mengambil ustadz tugas pada Pondok Pesantren Miftahul Ulum Panyeppen Pamekasan, sedangkan kurikulumnya tidak sama dengan kurikulum Pondok Pesantren Miftahul Ulum Panyeppen Pamekasan. 
Dalam hal pengembangan ekonomi masyarakat Jack Rohman menjelaskan bahwa ada tiga model konsepsi pengembangan masyarakat yang harus dipahami yaitu Pengembangan masyarakat lokal (locality development), Perencanaan sosial (social planing) dan Aksi sosial (social action) dari teori tersebut maka Pondok Pesantren Miftahul Ulum Panyeppen Palengaan Pamekasan dengan potensi yang dimiliki tersebut sudah melakukan perencanaan sosial (social planing) dengan pengetahuan yang diberikan melalui pelatihan-pelatihan, mengikut sertakan pada kegiatan training of trainer dan studi komperatif pada instansi yang sudah dianggap mapan dalam pengembangan ekonominya.

\section{Analisis peran dan kontribusi Pondok Pesantren Miftahul Ulum Panyeppen Pamekasan dalam mengembangkan ekonomi masyarakat}

Pengembangan ekonomi sudah dilakukan oleh Yayasan Al-miftah dengan KOIM Mawaddah begitu pula oleh masyarakat, tentu hal ini tidak menutup kemungkinan adanya kontribusi yang diperoleh oleh Pondok Pesantren Miftahul Ulum Panyeppen Pamekasan, begitu pula kontribusi itu dapat dirasakan oleh masyarakat dengan beberapa praktek pengembangan ekonomi yang telah dilakukannya. Oleh sebab itu peneliti membagi kontribusi itu menjadi dua (2) bagian. Sebagaimana berikut;

1. Internal pesantren

a. Fisik

Kontribusi yang sudah dirasakan Pondok Pesanten Miftahul Ulum Panyeppen Pamekasan dari pengembangan ekonomi yang lakukan oleh yayasan AlMiftah melalui KOIM Mawaddah adalah berupa fisik bangunan, baik pembangunan sekolah, jading santri, asrama santri putra, tempat pengiriman santri putri dan rencana pembangunan Rumah sakit berbasis ummat yang rencana akan diresmikan dan peletakan batu pertamanya akan dilaksanakan pada bulan April 2018 oleh KH. Ma'ruf 
Amin. Dimana kontribusi partisipatif Yayasan melalui KOIM Mawaddah untuk pembangunan pada tahun 2016 sebesar Rp. 955.000.000; dan pada tahun 2017 meningkat menjadi Rp. 1. 250.000.000; yang saat peneliti datang ke Pondok Pesantren Panyeppen sedang membangun asrama santri putra berlantai III dengan rencananya berjumlah 42 kamar. sebagaimana yang dijelaskan oleh KH. Muhdlar Abdullah ketua Yayasan Almiftah.

b. Non Fisik

Kontribusi yang diberikan dari hasil usaha pengembangan ekonomi Yayasan Al-miftah melalui KOIM Mawaddah, juga berupa non fisik, tetapi ini masih sangat sedikit sekali hanya berupa gaji karyawan, uang sabun pengurus pesantren, makan asatidz dan transport asatidz yang dari luar dan seragam semua pegawai yang berada di bawah naungan Yayasan Al-Miftah setiap akhir tahun. Hal ini selaras dengan yang dipaparkan oleh Ust. Bahrur Rosi wakil Koordinator pengurus bagian Pendidikan Agama sekaligus bertanggungjawab menghendel pengajuan uang bisyaroh Asatidz Pondok Pesantren Miftahul Ulum Panyeppen Pamekasan.

2. Eksternal Pondok Pesantren/Masyarakat

Pemberdayaan masyarakat merupakan cita-cita luhur Yayasan Al-Miftah dalam usaha-usaha yang dijalankan baik pendidikan, prilaku utamanya dalam mengurangi pengangguran dan kemiskinan, tentu dengan demikian Yayasan Al-Miftah sangat peduli untuk mengembangkan ekonomi masyarakat, guna untuk mencapai tujuan dan citacita mulia ini, Yayasan Al-Miftah melalui KOIM Mawaddah dengan usaha yang dikembangkannya, memberikan kontribusi yang sangat baik pada masyarakat. Adapun 
kontribusi yang diberikan Yayasan Al-miftah, peneliti menemukan ada empat (4) macam, yaitu;

a. Peminjaman dan Pemberian Modal Usaha

Kontribusi yang diberikan oleh Yayasan Al-Miftah bersama KOIM Mawaddah pada masyarakat dengan memberi pinjaman modal usaha dan ada pula yang diberi modal usaha untuk dikelola melalui akad qard al-hasan, hal ini dilakukan untuk memberi peluang pada masyarakat untuk mengubah kehidupan atau ekonominya yang semula berada di garis kemiskinan menjadi pengusaha, yang tentu dengan pemberian pelatihan kewirausahaan dan pengawasan yang intensif dari Pondok Pesantren Miftahul Ulum Panyeppen Pamekasan yang bersifat berkala dan berkesinambungan.

b. Penyediaan Lapangan Pekerjaan

Dalam penyediaan lapangan pekerjaan ini, Pengasuh Pondok Pesantren Miftahul Ulum Panyeppen Pamekasan melalui Yayasan Al-Miftah memerintahkan agar pengangkatan karyawan dan pegawai dari semua instansi yang berada dibawah naungan Yayasan Al-Miftah diambilkan dari golongan alumni dan masyarakat potensial yang tidak mampu ekonominya.

Dalam pemilihan karyawan dari alumni dan simpatisan atau masyarakat tidak mampu ini, diharapkan untuk membantu ekonomi masyarakat bebas dari kemiskinan dan mengurangi pengangguran yang acapkali terjadi dari kalangan lulusan pesantren dan terus membantu masyarakat mengenal tentang usaha yang berbasis shariah. Ini didukung oleh teori yang disampaikan oleh Jack Rohman yang menjelaskan bahwa untuk memahami konsepsi pengembangan masyarakat salah satunya adalah pengembangan masyarakat lokal (locality development) dalam artian masyarakat tidak dipandang 
sebagai klien melainkan dianggap sebagai masyarakat yang memiliki potensi.

c. Penyediaan Kios-kios

Pengadaan kios-kios kecil untuk menampung barangbarang jualan dari masyarakat untuk santri, kontribusi seperti ini diharapkan untuk memberi pekerjaan pada mereka sehingga dapat mengurangi pengangguran, membantu meningkatkan ekonomi dan meringankan beban kebutuhannya.

d. Pemberian beasiswa bagi anak berprestasi

Salah satu kontribusi yang diberikan oleh Pondok Pesantren Miftahul Ulum Panyeppen Pamekasan pada masyarakat adalah memfasilitasi dan memberikan biasiswa pada anaknya yang berprestasi. prioritasnya kepada santri yang berprestasi dibidang akademiknya baik dari pendidikan formal maupun pendidikan non formal. Hal ini diharapkan setelah lulus dari jenjang pendidikannya baik S1 maupun S2, mereka dapat menggunakan ijasahnya untuk mengangkat derajat keluarganya dan membantu meningkatkan ekonominya.

3. Faktor pendukung Pesantren Miftahul Ulum Panyeppen Pamekasan dalam mengembangkan ekonomi masyarakat

a. Cita-cita Pengasuh Pesantren.

Dalam pengelolaan lembaga keuangan shariah (BMT Mawaddah) selalu berpacu pada cita-cita pengasuh Pondok Pesantren Miftahul Ulum Panyeppen, untuk membantu mengembangkan ekonomi ummah/ masyarakat yang berbasis shariah menjadi faktor pendukung tersendiri bagi pengelola lembaga tersebut, yang sama-sama mempunyai komitmen untuk selalu melangkah lebih maju dengna menawarkan pola berbeda dari lembaga keuangan yang lain seperti margin lebih tinggi tanpa riba dan lain-lain karena pada dasarnya 
mereka harus mempertanggungjawabkan terhadap amanah yang diberikan pengasuh.

b. Pemberdayaan SDM

Salah satu faktor pendukung dalam mengembangkan ekonomi masyarakat dengan aktivitas dan usaha yang dilakukan oleh Pesantren Miftahul Ulum Panyeppen adalah pemberdayaan sumber daya manusia (SDM) dengan beberapa kegiatan seperti perolingan tempat kerja, memberi pelatihan setiap dibutuhkan, mengirimkan delegasi guna mengikuti pelatihan pada lembaga berbasis shariah yang lain yang lebih maju dan mengadakan liburan bersama guna membentuk kerjasama yang harmonis antar karyawan.

c. Kerjasama dengan lembaga lain.

Kerjasama dengan lembaga lain yang lebih mapan dan maju dari semua aspek seperti pola menejerial, menajemen pengelolaan dan strategi pengelolaan adalah salah satu faktor pendukung dari pengembangan ekonomi seperti yang dilakukan oleh pengelola mesin foto copy yang selalu intent dengan lembaga-lembaga sekitar utamanya lembaga yang ada dinaungan pesantren dan jalinan kerjasama yang dilakukan toko kitab dengan lembaga ranting serta lembaga yang berafiliasi dengan Yayasan Al-miftah dalam pengadaan kurikulum yang digunakan.

d. Konsumen tetap dan jelas

Keuntungan bagi masyarakat yang pengembangan ekonominya berbentuk usaha suppler barang ke Pondok Pesantren, tidak banyak menyita waktu, perputaran uang yang cepat dan masyarakat dapat melakukan pekerjaan lain, seperti pergi ke sawah mengurus pertanian atau pergi ke pasar untuk berdagang. 
4. Faktor Penghambat Pesantren Miftahul Ulum Panyeppen Pamekasan dalam mengembangkan ekonomi masyarakat

a. Persaingan yang semakin ketat

Banyaknya Pondok Pesantren yang mendirikan lembaga keuangan shariah menjadi hambatan tersendiri dalam pengembangan usaha lembaga keuangan walaupun persaingan tersebut masih dalam katagori persaingan sehat yang tidak menyalahi aturan shariah, hambatan ini berdampak sering terjadinya sesuatu yang tidak terduga sebelumnya seperti penipuan pemohon pembiyaan yang masih bisa mengelabuhi pengelola dengan menggunakan mas palsu yang dijadikan agunan, surat-surat kendaraan yang barangnya digadaikan kembali dan lain sebagainya.

b. Keterbatasan pengetahuan karyawan

Ketebatasan pengetahuan dan pengalaman dalam bisnis dan usaha pada karyawan merupakan salah satu faktor penghambat dalam mengembangkan usaha sehingga mereka tidak bisa untuk mengembangkan usaha yang dikelolanya bahkan stagnan pada pola satu usaha tanpa mengadakan inovasi baru dan tidak ada keinginan pada bisnis yang lebih profit oriented, hal ini terbukti dengan penutupan usaha wartel yang kalah bersaing dengan telpone genggam seperti HP dan penutupan toko pada saat santri libur.

c. Usaha berjangka waktu

Masyarakat yang usahanya hanya menjadi suppler barang ke Pondok Pesantren Miftahul Ulum Panyeppen tidak bisa menjalankan bisnisnya secara terus-menerus karna konsumennya tergantung kepada santri, disaat pondok libur dan santri pulang maka bentuk pengembangan ekonomi seperti ini tidak dapat dilakukan dan semua toko ditutup tentunya usaha masyarakat yang seperti ini tidak 
dapat diandalkan karena mereka tidak bisa mendapatkan penghasilan dari usaha lain.

d. Datangnya risiko alam

Dalam pengelolaan ternak ayam petelur risiko alam yang acapkali terjadi adalah penyakit flu burung yang tidak diketahui waktunya, hal ini berakibat besar pada kerugian yang akan diperoleh oleh bisnis ini, tidak menutup kemungkinan juga terjadinya pencurian terhadap ayam petelur yang diakibatkan karena jauhnya kandang ayam dari rumah warga.

\section{Penutup}

Peran dan Aktivitas yang dilakukan Pondok Pesantren Miftahul Ulum Panyeppen Pamekasan dalam mengembangkan ekonomi masyarakat sebagaimana berikut; (a). Peminjaman modal usaha dan pemberian modal usaha melalui qard al-hasan dari KOIM Mawaddah untuk dikelola untuk mengubah kehidupan yang semula berada digaris kemiskinan menjadi berpenghasilan. (b). Penyediaan lapangan pekerjaan dengan mengangkat karyawan dari semua instansi dan usaha yang dikelola yayasan Al-Miftah dari alumni dan masyarakat/simpatisan potensial yang tidak mampu. (c). Pengadaan kios-kios yang disiapkan pada masyarakat yang berdagang makanan ringan pada santri. (d). Pemberian biasiswa bagi anak berprestasi sehingga bisa membantu menjalankan program dan usaha yang dijalankan oleh pesantren.

Faktor Pendukung Pondok Pesantren Miftahul Ulum Panyeppen dalam mengembangkan ekonomi masyarakat 1). Cita-cita Pengasuh Pesantren untuk mengembangkan ekonomi ummat yang berbasis shariah. 2). Pemberdayaan SDM melalui perolingan tempat kerja, memberi pelatihan, mengirimkan delegasi dan mengadakan liburan bersama. 3). Kerjasama dengan lembaga lain dan 4). Konsumen tetap dan jelas karena terdiri dari santri, siswa dan mahasiswa. Faktor Penghambat Pondok Pesantren Miftahul Ulum Panyeppen dalam 
mengembangkan ekonomi masyarakat 1). Persaingan semakin ketat karena pondok pesantren yang mendirikan lembaga keuangan shariah dan mengelola usaha yang sama. 2). Keterbatasan pengetahuan karyawan dalam bidang kewirausahaan. 3). Usaha berjangka waktu, ini disebabkan santri ada waktu libur pondok dan sekolah. 4). Datangnya risiko alam secara tiba-tiba.

\section{Daftar Pustaka}

An-najah, Tim. Jejak Langkah Dan Kiprah Para Masyayikh Panyeppen. Pamekasan: Al Miftah Press, 2013.

Asrohah, Hanun. Pelembagaan Pesantren Asal Usul Dan

Perkembangan Pesantren Di Jawa. Jakarta: Departemin Agama RI, 2004.

Faozan, Akhmad. "Pondok Pesantren Dan Pemberdayaan Ekonomi." Jurnal Ibda 'Vol.4 No.1 (n.d.).

Fauzi, Yusni. "Peran Pesantren Dalam Upaya Pengembangan Manajemen Sumber Daya Manusia (MSDM) Entrepreneurship, (Penelitian Kualitatif Di Pondok Pesantren Al-Ittifaq Rancabali Bandung)." Jurnal Pendidikan Universitas Garut Vol.06 No. (n.d.):

Fitrianto, Achmad Room. "Peran Pesantren Dalam

Pengembangan Perekonomian Rakyat", Artikel (Diskusi Panel Penguatan Ekonomi Pesantren Dan Tantangan Perubahan Oleh Center For Islam And Democracy Studies." (Dosen Fakultas Syariah IAIN Sunan Ampel, Alumni Ekonomi Pembangunan Universitas Airlangga Surabaya) (n.d.):

Ghazali, M Bahri. Pesantren Berwawasan Lingkungan. Jakarta: CV. Prasasti, 2002.

Ife, Jim, and Frank Tesoriero. Community Development: Alternatif Pengembanga Masyarakat Di Era Globalisasi. Yogyakarta: Pustaka Pelajar, 2008.

Marlina. "Potensi Pesantren Dalam Pengembangan Ekonomi

Syariah." Jurnal Hukum Islam (JHI) Vol.12 No. (n.d.): 123. Rukminto, Isbandi. Intervensi Komunitas \& Pengembangan 
Masyarakat. Jakarta: Raja Grafindo Persada, 2008.

Suharto, Edi. Membangun Masyarakat, Memberdayakan Rakyat, Kajian Strategis Sosial \& Pekerjaan Sosial. Bandung: Reflika Aditama, 2017.

Syam, Nur. Kepemimpinan Dalam Pengembangan Pondok Pesantren, Manajemen Pesantren. Yogyakarta: Pustaka Pesantren, 2005.

Wahid, Marzuki. Pesantren Masa Depan Wacana Pemberdayaan Dan Transformasi Pesantren. Yogyakarta: Pustaka Hidayah, 2001.

Badrut Tamam, Bendahara IKBAS, Wawancara, Pamekasan, 17 April 2018

Bahrudin Habibi, Koordinator Pengurus, Wawancara, Pamekasan, 21 Pebruari 2018

Ismail, Manajer KOIM Swalyan Tlengir, Wawancara, Sampang, 06 Maret 2018.

Khozairi, Manajer KOIM Swalyan Karangpenang, Wawancara, Sampang, 10 Maret 2018.

Moh. Bahri, Manajer BMT Pusat, Wawancara, 12 April 2018.

Moh. Syawal, Penjaga Ayam Petelur, Wawancara, Pamekasan, 11 Maret 2018.

Muhdlar Abdullah, Ketua Yayasan Al-Miftah, Wawancara, Pamekasan, 16 Maret 2018.

Taufiqur Rohman, Ketua Unit Catering Santri, Wawancara, Pamekasan, 26 Pebruari 2018.

Thoif Wijaya, Ketua KOIM, Wawancara, Pamekasan 5 April 2018. 